\title{
Reversing Channels and Unsettling Binaries: Rethinking Migration and Agrarian Change under Expanded Border and Immigration Enforcement
}

\author{
Richard L. Johnson
}

Citation: Johnson, R.L. Reversing Channels and Unsettling Binaries: Rethinking Migration and Agrarian Change under Expanded Border and Immigration Enforcement. Land 2021, 10, 228. https://doi.org/10.3390/ land 10030228

Academic Editor: Mariel Aguilar-Støen

Received: 9 January 2021

Accepted: 19 February 2021

Published: 24 February 2021

Publisher's Note: MDPI stays neutral with regard to jurisdictional claims in published maps and institutional affiliations.

Copyright: (C) 2021 by the author. Licensee MDPI, Basel, Switzerland. This article is an open access article distributed under the terms and conditions of the Creative Commons Attribution (CC BY) license (https:// creativecommons.org/licenses/by/ $4.0 /)$.
School of Geography, Development \& Environment, University of Arizona, Tucson, AZ 85712, USA; rljohnson@email.arizona.edu

\begin{abstract}
Unauthorized migration under global regimes of border and immigration enforcement has become more risky and costly than ever. Despite the increasing challenges of reaching, remaining in, and remitting from destination countries, scholarship exploring the implications of migration for agricultural and environmental change in migrant-sending regions has largely overlooked the prevalent experiences and consequences of "failed" migration. Drawing from recent fieldwork in Central America with deportees, this paper demonstrates how contemporary migration at times reverses the "channels" of agrarian change in migrant-sending regions: instead of driving remittance inflow and labor loss, migration under contemporary enforcement can result in debt and asset dispossession, increased vulnerability, and heightened labor exploitation. Diverse migration outcomes under expanded enforcement also reveal a need to move beyond the analytical binary that emphasizes differentiations between migrant and non-migrant groups while overlooking the profound socioeconomic unevenness experienced among migrants themselves. With grounding in critical agrarian studies, feminist geographies, and emerging political ecologies of migration, this paper argues that increased attention to the highly dynamic and diverse lived experiences of migration under expanded enforcement stands to enhance our understanding of the multiple ways in which contemporary out-migration shapes livelihoods and landscapes in migrant-sending regions.
\end{abstract}

Keywords: migration; immigration enforcement; agrarian change; dispossession; Guatemala

\section{Introduction}

This paper explores how expanded border and immigration enforcement shape landscapes and livelihoods in migrant-sending regions. It demonstrates that our understanding of the implications of migration for agrarian change and other socioenvironmental dynamics can be greatly enhanced through closer attention to the highly varied and contingent experiences of contemporary migration under expanded enforcement regimes. The experiences of deportees and other "failed" migrants reveal alternative forms and pathways of agrarian change and social differentiation in migrant-sending regions.

Research spanning decades across disciplines and geographic regions has sought to understand the multifaceted implications of labor out-migration and remitting for migrant-sending families and communities. From the outset, this literature has taken a particular interest in how migration reshuffles land distribution and land use dynamics among rural migrant and non-migrant households [1-3]. In the ensuing years, the literature has expanded from these origins to form a robust body of work exploring the complex outcomes of migration for a gamut of agricultural, social, and environmental dynamics, as well as the multiple factors that shape trajectories of change across unique spatial and temporal scales [4-9]. With global migrations showing no sign of abating under intersecting economic, security, and environmental crises, continued research on migration and its implications for migrant-sending communities remains as relevant as ever. 
While this growing literature continues to enhance our understanding of the ways in which migration and remitting shape landscapes and livelihoods in migrant-sending regions, it has largely overlooked a dramatic shift in the experiences, contingencies, and outcomes of migration itself under the rapid global rise of border and immigration enforcement [10-14]. Reaching and remaining in destination countries under expanded enforcement regimes are increasingly risky, costly, and prone to failure. These challenges are particularly pronounced for migrants fleeing eroding economic and security conditions in Central America, Mexico, and elsewhere, who now face heightened levels of surveillance, interdiction, violence, and hardship throughout the journey to the US [14-19]. Federal funding of the US Border Patrol has increased from \$326 million to approximately $\$ 4.7$ billion from FY1992 to FY2019 [20], with Border Patrol staffing at the US southern border growing from 3555 agents in FY1992 to 16,731 agents over the same period [21]. In 2012, it was estimated that approximately 200 of the 300 individuals departing Guatemala for the US were deported from either Mexico or the US per day [22]. The deportation of Guatemalans from the US has doubled in the past decade, reaching 54,547 forced repatriations in 2019 [23]. Estimates suggest that approximately 550,000 undocumented Guatemalan nationals currently reside in the US [24], yet nearly 900,000 Guatemalans were deported from the US and Mexico combined between 2009 and 2019 [25]. Despite these efforts, the expansion of enforcement has widely failed to deter continued unauthorized migration attempts [26-31].

While scholars have carefully documented the rise of US enforcement, we are only beginning to understand the multiple consequences of this expansion for migrant-sending households and communities in countries of origin [32]. Amid recent contributions to this literature [18,27,33-38], we particularly lack an understanding of the socioeconomic and material implications of enforcement in migrant-sending regions [29]. This gap extends to scholarship assessing the outcomes of migration for processes of agricultural, environmental, and developmental change. Despite a steady growth in enforcement since the mid-1990s and scattered observations noting the enduring challenges of migration and instances of migrant deportation and debt [6,7,39], no known research has systematically examined enforcement outcomes for migrant-sending regions. To date, the literature has predominantly explored the complex outcomes of migration through conceptual and methodological approaches that emphasize migrant "success," remittance inflows, and local labor loss while overlooking the proliferating incidence and consequences of migrant precarity and "failure" from policing, apprehension, and deportation.

Recent research in Central America highlights how expanded enforcement generates new risks and costs for undocumented migrants. Rising smuggling fees fuel widespread migrant indebtedness, while apprehension and deportation in turn foster deep economic hardship that can drive the sale or dispossession of homes and land leveraged to fund migration attempts [29,40-42]. These findings reveal how migration under expanded enforcement drives novel forms of agrarian change in migrant-sending regions. In other words, in contrast to the "remittance landscapes" [6] emphasized in recent scholarship, contemporary migration experiences and outcomes appear to generate alternative "enforcement landscapes" in countries of origin.

Building from past research on migrant debt, deportation, and dispossession in Guatemala [29], and with grounding in critical agrarian studies [43], feminist geographies [44,45], and political ecologies of migration [46], this article offers a case study on the formation of enforcement landscapes in migrant-sending regions. I argue that migration under expanded enforcement produces alternative pathways of change to those emphasized in the literature through mechanisms of migrant debt, property loss, and the growth of a highly exploitable local labor pool. The experiences of deportees also reveal the profound unevenness generated within migrant cohorts. This differentiation is largely obfuscated in contemporary research that groups and evaluates migration consequences among migrant and non-migrant households. The distinct experiences of deportees suggest a need to move beyond this conceptual binary to capture greater complexity in migration outcomes. In sum, I argue that our understanding of the implications of migration for migrant-sending 
communities can be enhanced through greater attention to the highly challenging and dynamic nature of migration itself.

This article first provides a brief review of the literature exploring the consequences of migration for agricultural, environmental, and socioeconomic change, with a focus on scholarship in Latin America. I then highlight some of the conceptual and methodological shortcomings of the current literature, particularly as they relate to the shifting realities of contemporary migration under expanded enforcement. The following section charts the expansion of US border and immigration enforcement since the mid-1990 and its consequences for undocumented migrants seeking to enter and remain in the US. Following an overview of fieldwork conduced in Guatemala and this study's conceptual orientation, I then present research findings revealing how different facets of expanded enforcement come to shape livelihoods and landscapes in migrant-sending regions. Findings include an overview of common trends in migrant debt, deportation, and property loss among the research sample and three brief case studies highlighting reversed channels of agrarian change and the production of difference among deportees. This article concludes with outstanding research topics and questions.

\section{Literature Review}

\subsection{Migration and Agrarian Change}

Over the last four decades, scholars have conducted extensive research assessing the diverse implications of international labor out-migration for migrant-sending communities. The roots of this literature in the Americas stem from initial studies conducted in rural Mexico beginning in the late 1970s and early 1980s [1-3,47], with Reichert observing in 1981 that almost no prior research had explored "the effects of U.S.-bound migration on Mexican sending communities" [3] (p. 56).

Early research was primarily interested in assessing the developmental implications of migration and their downstream consequences for evolving migration streams. Given the rural context, "development" (or the absence thereof) was evaluated in terms of the possibilities and practices of "productive" economic investments in land, agriculture, or other ventures by migrant households with newfound remittances, yet under the constraint of reduced local labor availability from out-migration. Impacts were generally assessed through comparative analysis of the economic realities and opportunities of migrant households relative to their non-migrant counterparts, such as uneven patterns of land access among the two cohorts [2,3,47-50].

While debates on migration's developmental implications continue [48,50,51], these initial studies sparked a line of research exploring the implications of migration for agricultural and environmental dynamics at different scales. As Jokisch [7] and others $[5,9,39]$ outline, scholars examining agrarian change initially observed instances of migration fostering agricultural degradation or abandonment [52-54], investment and intensification $[1,55,56]$, or other "middle path" engagements with land and production, such as geographically extensive and labor-light production strategies $[9,57,58]$. Each of these land-use change trends have been observed in Guatemala across diverse geographical and temporal scales $[9,39,55,59,60]$.

More recent work, however, has demonstrated that trajectories of agrarian and environmental change are challenging to assess, scale dependent, and highly conditioned by intersecting structural circumstances, with migrants typically investing in land and agriculture only when concrete productive opportunities exist [61]. Accordingly, current research has largely departed from attempting to claim definitive trajectories of change and instead aims to reveal the diverse contextual factors and conditions through which situated processes of agrarian and environmental change unfold. Scholars have observed a number of factors mediating the character of agrarian change in unique contexts, including political-economic dynamics at multiple scales [7,9]; land tenure arrangement and land quality [5]; policies, institutions, and incentives [55]; gender and family dynamics [5,62]; and spatial "imagined futures" [63]. Longitudinal research by Taylor et al. [9] in Guatemala 
highlights how changes to agrarian systems from migration are neither unidirectional nor permanent amid shifting obstacles and opportunities at different scales. Similarly, research assessing the developmental consequences of migration has transitioned from debating "whether migration has either positive or negative developmental impacts" to "why migration has contributed to development in some communities and much less, or even negatively in others" [49] (p. 7). That said, scholars have found that migrant households tend to accumulate more land than non-migrant households [9,55], and that subsequent inflationary pressures often push assets and properties out of reach for many.

The literature has made substantial strides in improving our understanding of migration and agrarian change dynamics across space and time. Yet, amid these advancements, scholarship by and large continues to draw on a conceptual model developed in earlier research that holds the intersecting "channels" of remittance inflows and reduced labor availability as the central drivers of change from migration [8,61]. The bulk of research also continues to measure change through comparative assessment of various socioeconomic indicators between migrant and non-migrant households. In doing so, the literature has largely overlooked a dramatic shift in the conditions and outcomes of migration itself over the last several decades and their role in driving unique forms of change in migrant-sending regions.

\subsection{Expanding Geographies of Enforcement}

In the past quarter century, expanding geographies of border and immigration enforcement have made undocumented migration increasingly costly and perilous, with profound ramifications for the physical, emotional, and financial well-being of migrants, their families, and migrant-sending communities. While this article focuses on expanding enforcement in the Americas, other scholars have examined the growth of enforcement as a broader global trend emerging in different forms and spaces between traditional migrant-sending and migrant-receiving territories [10,11,64-66].

The contemporary US border and immigration enforcement paradigm stems from efforts in the mid-1990s under the Clinton Administration to dissuade unauthorized border crossings through a strategy of "prevention through deterrence." The strategy was premised on the belief that increased costs, challenges, and dangers to unauthorized border crossing would deter potential entrants from making attempts $[12,15,16,67,68]$. The strategy involved sealing off historic urban crossing zones, such as San Diego, CA and El Paso, TX, to make the rugged US-Mexico borderlands the only variable path of entry. Policymakers believed that migrants would be disinclined to expose themselves to the heightened costs and hardships of remote crossings. Moreover, as de León [68] observes, funneling migrants into the borderlands was thought to isolate unauthorized crossers for easier apprehension.

Despite failing to halt migration attempts, policymakers have continued to double down on the strategy of increasing the costs, dangers, and penalties of attempted entry. Enforcement grew throughout the 2000s, with the September 11, 2001 attacks prompting the Bush Administration to expand border staffing, surveillance, and barriers under new anti-terrorism and national security initiatives [27]. Over this period, enforcement also turned inward, expanding efforts to apprehend and deport migrants living and working in the US without documentation $[69,70]$. In the late-2000s and early-2010s the Obama Administration enacted the "Consequence Delivery System" - a gamut of enforcement strategies "designed to make the experience [of apprehension] so difficult and costly that migrants [would] not return" [31] (p. 110) [16,19].

Over the last two decades, a range of US-driven enforcement efforts have also expanded into new spaces in the Americas. Regional security initiatives, such as Plan Frontera Sur in Mexico and Plan Venceremos in Central America, as well as a collection of other international partnerships with foreign government agencies [71], have resulted in a substantial increase in the apprehension and deportation of foreign nationals by the Mexican government [72]. These efforts have effectively created a new "vertical border" [17] across areas of migrant transit in Mexico [14,73,74]. 
Under the Trump administration, unauthorized migrants faced the expansion of the US border wall and security infrastructure [75], increasingly abusive and punitive treatment in detention, including family separations [76,77], more direct involvement of Customs and Border Protection agents in the apprehension and deportation of foreign nationals in Mexico and Central America [78], the erosion of asylum rights and protocols [79], public health and safety disasters in border encampments under the Migrant Protection Protocols [80,81], a renewed emphasis on internal apprehensions [82], and proliferating violence throughout Mexico [18,83] and increasingly at the Guatemala-Mexico border [84]. While the new Biden administration has already taken steps to end a number of Trump-era policies [85], the core elements of border and immigration enforcement currently remain in place.

Expanded enforcement and the emergence of the contemporary "polymorphic" border [86] have made migration progressively more difficult for Central Americans and others. Amid estimates of fluctuating rates of unauthorized migration from Guatemalan beginning in the mid-2000s [87], followed by more consistent growth since the mid-2010s [24], the deportation of Guatemalan nationals from the US grew by approximately $370 \%$ over the same timeframe, from 11,500 in 2005 to 54,600 in 2019. When including removals from Mexico, the total deportations for 2019 nearly doubles, rising to 103,700 [88]. The expansion of US border enforcement has empowered human and drug smuggling cartels and exposed migrants to untold horrors of violence and exploitation in Mexico [14,18,19]. These dangers and the "commodification" of migration [14] have substantially increased the price of entry to the US. Data from fieldwork conducted for this article reveal that the cost of hiring a smuggler or coyote to travel from Guatemala into the US grew from approximately $\$ 500$ in the late 1980s to approximately $\$ 5000$ in the mid-2000s and now upwards of $\$ 10,000$ (with rates of inflation and currency exchange remaining relatively constant over that time period). Instead of deterring potential attempts, these elevated costs often bind migrants to cycles of debt-driven return migration to pay smuggling loans [29]. The weaponization of the borderlands has led to a tragic growth in migrant death and disappearance, with at least 300-500 known migrant deaths recorded near the border every year $[19,25,67,89]$ and a more recent increase in the ratio of deaths to migration attempts [90,91].

\subsection{Towards Enforcement Landscapes}

A handful of scholars contributing to migration and agrarian change literature have made important observation on the enduring challenges and heightened costs of reaching and remining in the US. For example, Durand and Massey [1] and Durand et al. [56] observe how migrants often first channel the bulk of their early remittances towards smuggling loan repayment. Jokisch notes that deportees in Ecuador "must pay off the debt or lose the family landholdings, or whatever else they used as collateral" for smuggling loans [7] (p. 531). Jokisch also observes the "precariousness of the remittance economy" for migrantsending families, given the multiple obstacles to safe arrival and securing work in the US (p. 541). In Guatemala, Moran-Taylor and Taylor [59] as well as Aguilar-Støen et al. [39] report instances of prospective migrants mortgaging or selling land to fund migration attempts, with the latter study also finding outstanding debt burdens among some returnees. Hostettler in Mexico notes the "highly variable" consequences of migration, with some migrant-sending families "[suffering] from a "failed" migration attempt due to large loans that were taken in order to finance migration" [6] (p. 126). Cohen notes that "national borders remain obstacles for many migrants" [48] (p. 99), yet puzzlingly dismisses their possible role in shaping migration and remittance outcomes. Furthermore, while scholars widely recognize that migration outcomes are heterogenous [50], analysis of differentiation has generally centered on comparative work between migrant and non-migrant households. Recent research by Carte et al. [92] observes uneven socioeconomic outcomes among migrant cohorts, yet between groups engaged in distinct migration and political-economic processes from different migrant-sending countries. 
Despite these observations, no known research has systematically explored the wider consequences of "failed" migration and debt for livelihoods and landscapes in migrantsending regions. The bulk of research on migration and agrarian change has largely overlooked the highly dynamic and precarious nature of contemporary migration- a process that "always remains ongoing" [93] (p. 1). As Vogt observes from research in Mexico with migrants in transit, "[m]igrant journeys are rarely neat or linear and complicate traditional conceptualizations of migration from departure to arrival." Instead, "migration is a complex, makeshift, and often ambiguous lived experience that depends on and reconfigures processes of social exclusion and inequality" [14] (p. 766). Others have emphasized that, even upon reaching the US, many migrants experience a persistent condition of "deportability" - "the protracted possibility of being deported-along with the multiple vulnerabilities that this susceptibility for deportation engenders" [13] (p. 14). Harrison and Lloyd [94], for example, observe heightened migrant labor exploitation in the US due to deportability and the urgency of paying outstanding migration loans. Recent work by Boyce and Launius [95] reveal the extreme financial burdens experienced by undocumented or mixed-status families exposed to immigration enforcement in the US. With approximately 83,500 Guatemalans deported on average from the US and Mexico combined each year since 2010, success is far from guaranteed.

The lived experiences of deportees and others underscore the need to align scholarship on migration and agrarian change with the realities of migration under expanded enforcement. Attending to the range of contemporary migration outcomes, including alternative "channels" of change and the unevenness produced within migrant cohorts, is crucial for understanding of how migration shapes livelihoods and landscapes in migrant-sending regions. Research with deportees also underscores the urgent need to fill the empirical gap on enforcement consequences. The mounting risks, costs, and penalties of migration reverberate through migrant-sending households and regions in ways that scholars are only beginning to recognize.

\section{Materials and Methods}

This article draws from data gathered during 18 months of fieldwork between late2017 and mid-2019 in two distinct regions of rural Guatemala, including the community of Llanos del Pinal near the city Quetzaltenango in the western highlands and a constellation of small rural communities around the town of Caballo Blanco, Retalhuleu on the Pacific lowlands. The two research sites were selected in order to conduct comparative analysis on migration and agrarian change trends in two distinct agro-ecological zones. Research builds off of past work on migrant indebtedness in a separate town, Cajolá, approximately an hour from Quetzaltenango in the western highlands [29].

Data collection occurred through semi-structured qualitative interviews primarily with individuals who had experienced some form of apprehension and deportation from the US and/or Mexico. The research sample includes the experiences of 60 unique migrants, mostly young to middle-aged men, split nearly evenly between the two study regions. Subjects recounted migration experiences that ranged from a handful of initial crossings in the late-1980s and early-1990s to as recently as 2018, with the majority occurring between 2012 and 2018. Interviews explored participant livelihoods and productive assets; migration histories and funding strategies; experiences with transit, border crossing, apprehension, detention, and deportation; and the wider socioeconomic outcomes of failure upon return to communities of origin. Interviews also included baseline quantitative data collection on migration finance and debt. An additional 12 local leaders were interviewed to explore overarching community histories and shifting experiences with agrarian livelihoods, migration, and expanded enforcement. Research also revealed an alarming number of families, particularly in the western Highlands, who had experienced the disappearance of kin during crossing attempts at the US-Mexico border. One individual openly shared her experience with the disappearance of her spouse. Although migrant disappearance and death have been found to plunge households into extreme economic hardships [29], no 
additional interviews exploring these dynamics were pursued due the extreme sensitivities of the subject. Research also involved a handful of interviews with local banks and lending cooperatives about migration lending policies, practices, and observations. Ethnographic notes were recorded throughout fieldwork to assess everyday dynamics and meanings around migration, debt, and agrarian change. Interviews were gathered primarily though snowball sampling and the assistance of local leaders. Informed consent was obtained from all subjects involved in this study. Interviews were transcribed and coded to reveal key dynamics and relationships within and across individual cases and research sites. Quantitative data extracted from interviews were also tabulated to provide an overarching view of shifting trends in migration and deportation, the political economy of migration finance, and deportee debts and asset transfers following failed attempts.

Research was informed by emerging literature from critical agrarian studies, which maintains a keen interest in "analyzing agrarian social classes and the political-economic forces that call them into existence or make them disappear, and that facilitate or impede their reproduction" [43] (p. 963). This focus on differentiation was complimented by recent scholarship on the "political ecology of migration" that "considers migration within its historical and political context, with an emphasis on underlying structural explanations and a consideration of outcomes from a social justice perspective" [46] (p. 265). A political ecology of migration offers a "holistic" view of the multiple, intersecting factors that shape migration decision and their outcomes. Finally, research drew from perspectives in feminist geography, which "start from the subject" [96] (p. 200) and their everyday lived experiences to highlight previously overlooked "scales, voices, and topics" within wider social, economic, and political processes [44] (p. 329). In migration research, this approach "facilitates drawing connections between policymaking and the everyday lives of migrants" [37] (p. 294) [97]. As Vogt notes, "[m]igration is not just a livelihood strategy but also a material and embodied lived experience" [14] (p. 776).

Both research communities are comprised of primarily semi-substance households, drawing on a mix of traditional and market-oriented agriculture and intermittent jornadas (agricultural day labor) and other forms of seasonal wage labor when available. Rural households in the lowlands rely on small parcels to grow milpa or just maize for consumption and sale, followed by a second harvest of sesame as a cash crop. In the dry seasons many seek work on the nearby sugar cane and palm oil plantations. In the highlands, producers rely on even smaller parcels to grow milpa for consumption and assorted vegetables for bulk sale in nearby markets in Quetzaltenango. Proximity to Quetzaltenango also enables some to find work in construction, businesses ventures (particularly in the markets), and other urban jobs. Jornada and seasonal labor wages in both regions typically range between $\$ 4$ and $\$ 6.50$ per day.

Numerous scholars have examined Guatemala's prolonged history with international labor migration and the multiple drivers that continue fuel rural displacement. Contemporary rural out-migration stems from the development of an extractivist agrarian economy that has historically dispossessed communities, particularly indigenous groups, to secure land and foster rural dependency on seasonal migration to plantations for wage labor $[98,99]$. Entrenched patterns of internal labor migration began to extend outwards to Mexico and the US in the late-1970s with the intensification of the armed conflict and genocidal "scorched earth" campaign aiming to eliminate guerrilla insurrection against the stranglehold of national and international elites on lands, natural resources, and political power. Many fled to the US for asylum, while others joined northward streams in search of economic opportunities in the wreckage of the conflict [87].

While the 1996 Peace Accords formally ended the conflict, enduring structural challenges and inequalities ensured the continuation of out-migration flows [87]. New postconflict neoliberal reforms favored expanded agrarian extractivism and other mining and energy "megaprojects" to the detriment of smallholder production, land access, and labor opportunities [92,100-102]. Today, many smallholders live under a condition of "slow displacement," in which prolonged neoliberal political-economic governance "[provokes] 
a kind of displacement from the land that [unfolds] slowly over years" [92] (p. 2). With average landholdings remaining insufficient to meet basic household subsistence [103], rural poverty rates reaching $75 \%$ [104], rural incomes hovering around $\$ 2350$ annually [105], and two-thirds of agricultural land held by only $2.5 \%$ of farms [104], migration is necessary for both the immediate and generational social reproduction of rural families.

Overarching national trends in migration are reflected in both research sites. While no community directly experienced violence from the armed conflict, the heightened tensions, economic ruin, threats of forced recruitment by the military, and apparent success of others in the US led many to depart. Growth in migration continued throughout the 1990s and, according to some local leaders, reached its apex in the 2000s. Although flows have perhaps reduced slightly since the 2000s, they remain unquestionable strong as structural conditions continue to undermine the viability of rural livelihoods. Deportation remains so common that one local leader in the highlands referred to it as "customary." Participants in both regions noted the challenges of agricultural production due to low and variable commodity prices, the high cost of inputs, limited land access, and unending cycles of agricultural debt. Most smallholders expect to lose money in corn cultivation and, if yields are adequate, balance out losses with a slight profit in cash crops and/or wage labor. Farmers in both the highlands and lowlands have also struggled under variable precipitation patterns in recent years. While additional research is needed to establish concrete links between global climate change and migration, changes to seasonal precipitation and temperatures in Central America are likely to exacerbate existing challenges for producers [106,107]. A growing frequency and intensity in extreme climate events, such as recent 2020 Hurricanes Eta and Iota, also appear poised to propel new climate refugees north in the coming years [108].

Many participants identified cycles of fruitless investments and outstanding debts in agriculture as immediate drivers of decisions to migrate. Even if smallholders profit, the total income is typically insufficient to overcome an enduring state of deprivation or fund bigger projects, such as expanding production, investing in businesses or education, dealing with health emergencies, or buying tools and property. As the mother of one migrant remarked on the realities of rural life: "we're really just giving our parasites something to eat." Land prices are inflated to the point that it is virtually impossible to purchase additional properties for expanding production, building a home, or fulfilling social norms of passing land to the next generation without remittances.

As explored in past work [29] and observed by others [40-42], the heightened cost of migration to the US coupled with limited wages and work opportunities in migrantsending communities push many to fund migration attempts through loans from local moneylenders, banks and lending cooperatives, neighbors, and family members. According to participants and fieldwork observations, the overwhelming majority of contemporary migrants fund their journeys partially or totally through debt. Given the elevated loan amounts and heightened risks, lenders (with the exception of loans between family members) demand high-value properties as guarantees, typically homes and land. In many cases moneylenders require a compraventa contract that legally transfers ownership of the mortgaged property over to the lender until the borrower pays in full. This arrangement places borrowers under substantial vulnerability, as it gives lenders the right to evict families and take full possession of mortgaged properties at any time over the course of the loan. Lenders also impose high interest rates, both simple and compound, usually ranging from $3 \%$ to $10 \%$ per month over a one-year timeline, to pressure quick repayment and extract value from migrant labor in the US.

Detention and deportation provoke an acute economic crisis for many indebted migrants. Debt obligations, ballooning interest, the tangible threat of property dispossession, and no real means to repay loans while in custody or on meagre local wages create a heightened urgency to immediately return to the US. As observed in past research [29], the hardships and vulnerabilities of deportation and debt also prompt a kind of household "structural adjustment" [109], in which families reduce expenditure and intensify economic 
activities to generate capital for loan repayment. Currently there are no known state or non-governmental efforts to support indebted deportees. Some participants received support from church organizations or wider social networks. Yet, by and large, one's debts are viewed as one's own responsibility, while the shame and taboo of deportation inhibit others from seeking assistance.

Even for those who reach the US, debt repayment is a substantial burden amid the heightened costs of living in the US, the need to support family back home with remittances, variable work opportunities and suppressed wages, and constant threats of apprehension and deportation. One deportee observed how, in the initial months after reaching the US, he budgeted one-quarter of his monthly wages to cover expenses in the US, another onequarter to support his family in Guatemala, and the remaining half to repay his smuggling loan. For successful migrants who find steady work in the US, it can take anywhere between six months and two years to repay debts in full.

While certainly possible, dispossession is not a predetermined outcome of deportation [29]. Indeed, many deportees eventually make it to the US and repay their loans. Or, in other cases, moneylenders offer some degree of patience with deportees or among those struggling under limited work opportunities in the US. In other cases, households collectively manage to work off debt burdens, or family in the US step in to repay loans and take possession of mortgaged properties. Yet, as the findings below demonstrate, other less fortunate migrants eventually succumb to debts and lose properties through dispossession and forced sale. Moreover, with every failure, the means to secure new loans and make additional return attempts dwindle.

\section{Results and Discussion}

When Edwin (all names are pseudonyms) attempted to reach the US for the first time in 2000, his aim was, as he put it: "to not have to eat just beans and greens, but to eat something more." He hoped to save money to build a house on the piece of land he was slated to inherit from his father, and also buy additional agricultural parcels to: "live better, do something for my family, have a future." These were goals he could never achieve as a land-poor day laborer, seasonally earning between $\$ 35$ and $\$ 45$ a week on the Pacific lowlands. Edwin's father supported the idea and helped Edwin secure a \$1600 loan at $5 \%$ monthly interest from a local moneylender using family land as the guarantee. The $\$ 1600$ loan would pay for his trip to the US-Mexico border, where he would then get a second loan from family already in the US to pay the salto (border crossing). Although he made it through Mexico without incident, Edwin got lost in the unfamiliar borderlands on his crossing attempt and was eventually detained and deported back to Guatemala. His original debt quickly grew to surpass $\$ 2600$ and, seeing no alternatives to stem the tide, Edwin's father sold 16 cuerdas (approximately 0.7 hectares), including the portion Edwin was set to inherit, to pay.

With even greater urgency to reach the US and recoup losses following the fracaso (failure) from his deportation and land sale, Edwin tried again a few years later in 2005. his time he borrowed $\$ 2400$ at $6 \%$ interest per month to cover the journey to the border. Yet, he was again detained and deported — now from Mexico—on three consecutive attempts. With growing debts, no resources to make any additional trips, and still reeling from the sale of his family's land, Edwin was pushed into sharecropping on a nearby plantation-a fate reserved for the "most screwed" according to one local leader, in which, for a small fee, farmers first grow their own corn on plantation land in exchange for then cultivating a second crop of sesame or forage crops along with completing other odd tasks for the landowner. It took Edwin approximately four years of sharecropping to pay off his debt. "Deportees", he remarked, "don't even come back to more beans, we come back to just tortillas. Why? Because we lose the little we have, and we go, and la migración grabs us, and it's over." To date, Edwin has been unable to extract himself from sharecropping to provide for his family. 


\subsection{Reversed Channels of Change}

Research with deportees reveals a vastly different set of experiences, outcomes, and drivers of change for livelihoods and landscapes in migrant-sending regions than those emphasized in past research. Instead of reaching the US and remitting, an untold number of Guatemalans experience debt, hardship, asset loss, and exploitation. Aggregate research data from this case study provide a stark image of the risks, costs, and value extracted from contemporary migration under expanded enforcement. The vast majority of migrants interviewed for this research - 55 out of 60 -funded their trips either partially or totally through loans. Of the five outstanding migrants who funded their trips without loans, one individual funded his attempt through a land sale, one opted not to divulge the funding source, and the remaining three funded their attempts through savings or gifts. Those who relied entirely on savings or gifts either made their attempts during the 1990s for a substantially lower rate than current prices, or in one case failed to enter the US and paid only the smuggling advance. Among those who borrowed, research recorded a total of 123 migration loans, indicating that individual migrants are often forced to borrow from multiple sources, and/or across multiple attempts. As Table 1 below highlights, migration loans are secured from a variety of sources, predominantly local moneylenders and family in the US. Borrowing from family in the US helps prospective migrants avoid risky and usurious arrangements with moneylenders. For those lacking mortgageable properties or other assets in Guatemala, a loan from family in the US may be their only ticket north. Borrowers used homes or agricultural land to guarantee loans in nearly $40 \%$ of the total cases. Migrants with loans from moneylenders, banks, and local friends noted interest rates ranging from $3 \%$ to as high as $15 \%$ per month, with the majority falling between 4 and $7 \%$ per month. Banks and lending cooperatives typically offer lower interest rates but have a number of prerequisites and policies that complicate (and technically prohibit) borrowing for migration among smallholders.

Table 1. Migration Funding Sources.

\begin{tabular}{cc}
\hline Loan Source & Recorded Loans \\
\hline Local Moneylenders & 31 \\
\hline Friends in Guatemala & 13 \\
\hline Family in Guatemala & 7 \\
\hline Banks or Cooperatives & 15 \\
\hline Friends in the US & 7 \\
\hline Family in the US & 42 \\
\hline Unknown/Unspecified & 8 \\
\hline Total & 123 \\
\hline Mortgaged Property & Recorded Mortgages \\
\hline Homes & 26 \\
\hline Agricultural Land & 23 \\
\hline Total & 49
\end{tabular}

Data from research sample recorded through interviews. Mortgages are components of the recorded loans and do not represent separate or additional borrowing arrangements. At times, mortgages included both homes and small parcels of attached or proximate agricultural land.

Loan amounts varied over the timescale of the sample, reflecting increases in the smuggling price. Trip loans ranged from $\$ 500$ in 1989 to approximately $\$ 5500$ in the mid2000 s and $\$ 12,000$ in 2018. In a handful of cases, the total borrowed exceeded $\$ 12,000$ to cover additional bail and lawyers' fees incurred during detention in the US. The total amount of capital borrowed for migration in the sample (including banks, moneylenders, and family loans) reaches at least $\$ 350,000(\mathrm{Q} 2,633,375)$. When including non-loan capital, 
such as savings, land sales, and family gifts, the total leveraged to fund migration climbs an additional $\$ 295,500(Q 2,216,750)$ to reach at least $\$ 645,500$, before interest. The additional cost of accrued interest unfortunately remains unknown, as some participants struggled to precisely recall circuitous repayment histories, neglected to record the grand total repaid across diverse and at times shifting borrowing arrangements, or still had pending cases and could not yet articulate or project the total amount of interest paid. Yet, several cases revealed that accrued interest often approaches or even exceeds the loan principal for higher-interest loans or cases of delayed repayment, effectively doubling one's debt.

Of the 60 migrants interviewed for this research, subjects reported 95 total deportations among 106 total migration attempts. As Table 2 below highlights, migrants experienced apprehension and deportation from both Mexico and the US.

Table 2. Deportations and Migration Asset Transfers.

\begin{tabular}{cc}
\hline Deportation Origin & Deportation Count \\
\hline US Border Apprehensions & 52 \\
\hline US Internal Apprehensions & 30 \\
\hline Mexico Apprehensions & 13 \\
\hline Total & 95 \\
\hline Migration Asset Transfers & Asset Transfer Count \\
\hline Land Sales to Fund Migration & 3 \\
\hline Land Sales to Repay Debts & 7 \\
\hline Home Sales to Repay Debts & 1 \\
\hline Land Dispossession from Debts & 2 \\
\hline Home Dispossession from Debts & 4 \\
\hline Total & 17 \\
\hline
\end{tabular}

Data from research sample recorded through interviews.

Research recorded 17 asset transfers to fund migration or repay outstanding migration debts. Eight properties were sold to repay smuggling loans, while four homes and two additional agricultural parcels were dispossessed. At least three migrants sold agricultural land to help fund their trips. An additional 18 cases remained open at the time of research, with outstanding debts that may result in return attempts, property sale, and/or dispossession in the future. Forty-two participants were no longer in debt at the time of our interview following loan repayment, property sale, or dispossession. Dispossessed properties were mostly homes, which are more frequently used for loan guarantees given their higher value. Sold properties to repay debts were almost uniformly agricultural lands, usually to avoid the dispossession of mortgaged homes.

The fate of sold or dispossessed property remains somewhat opaque. Among sold properties, assets were often purchased by "successful" migrants looking to invest in homes or land for their families and/or planning eventual return to Guatemala, a trend that cruelly transfers assets between those with differentiated exposure to enforcement. In one illustrative instance in the Pacific lowlands, a milpa parcel belonging to a heavily indebted deportee was sold to a migrant in the US who intended to convert it into a small mango field until she eventually returned to Guatemala to build a home. As remittances often inflate local property prices [110], it is frequently only the families with ties to the US who can afford to purchase land in the first place. The destiny of dispossessed properties is less clear. Participants observed that moneylenders typically sell acquired properties to recoup lost loan capital and seek profits in real estate. Yet, dispossessed families are not often involved in this process and may not concretely know who ultimately takes possession of their former holdings. In other cases, participants suggested that lenders put agricultural lands under cultivation or rent them out to others. Many participants 
were visibly reluctant to speak about their former properties in great detail, likely due to the pain and shame associated with the loss of family homes and land, discomfort with sharing intimate details, or fears of potential conflict. Regardless, findings indicate that enforcement creates and exacerbates inequitable distributions of land and resources in migrant-sending communities.

Edwin's experiences, including his deportations, land sale, and subsequent sharecropping, illustrate some of the outcomes of expanded enforcement and a reversal in the "channels" of agrarian change stemming from migration. Asset transfers and loan repayments constitute a dramatic extraction of value from contemporary unauthorized migrants and deportees. The urgency to generate capital for debt repayment and the proletarianization of dispossessed smallholders subsequently reinforce local access to labor power. These circumstances force many into conditions of heightened labor exploitation in the wage economy. As Edwin observed towards the end of our interview: "in farming there are risks ... you win or lose ... just like going to the United States, a risk. If you head for the United States and cross, you win. In la milpa, you have a good harvest, you win. But if you don't, you lose. Then you lose money. You lose money".

\subsection{Beyond the Binary}

While land transfers and wealth extraction are most evident among deportees, they also occur among those who enter and establish themselves in the US. Beyond illustrating alternative channels of agrarian change, these transfers reveal distinct migration experiences and outcomes that are frequently overlooked or homogenized in comparative analysis between migrant and non-migrant households. This conceptual binary often misses the profound unevenness produced within migrant groups from the highly dynamic and perilous process of contemporary migration.

Marcos, for example, lost his home and agricultural land only after reaching the US, where intersecting precarities from his undocumented status inhibited debt repayment. In 2003, Marcos found himself in debts exceeding $\$ 6600$ after consecutive years of depressed crop prices made it impossible to repay bank loans obtained to invest in vegetable production. As Marcos told his wife: "I can't give any more to this debt. I'm going to get another loan, but I'm going to the US." He took out two \$2600 loans from separate local moneylenders to cover the $\$ 5200$ smuggling fee-one loan guaranteed by his home at $7 \%$ per month compound interest and another guaranteed by four cuerdas (nearly 0.2 hectares) of agricultural land at $7 \%$ simple interest per month.

Following one deportation back to the US-Mexico border on his first attempt, Marcos crossed into the US on his second try and eventually found work in Atlanta, GA. He quickly paid off his initial agricultural debts and began making payments on his migration loans while also supporting his family back home and covering his own expenses in Atlanta. Yet, the persistent socioeconomic vulnerability that fueled his decision to migrate from Guatemala followed him to the US. An employer robbed him of seven months of wages by stringing him along with a fraction of his owed income and false promises to eventually pay in full. When Marcos finally confronted his boss about the missing wages, he threatened to have him deported. Then, his wife fell ill and required a surgery that forced Marcos to take out a sizable loan in Guatemala to cover the expenses. Following his wife's surgery, Marcos then fell from a roof during a construction job and due to injury was unable to work or remit for several months. After four years of inconsistent work, exploitation, and ballooning interests, his original migration loans came due. He was first dispossessed of his four cuerdas of agricultural land, deciding to sacrifice it in order to prioritize repayment of the debt threatening his home. Yet, the following year, the second lender ran out of patience and evicted Marcos's wife and children after selling their mortgaged house out from underneath them. Marcos worked another two years to try to recoup his losses but was eventually detained and deported, now homeless and landless, back to Guatemala in 2010. The dispossessions forced Marcos and his family to move in with his brother in law. Back home, lacking cuerdas of his own, capital to rent land and cultivate, or encouraging 
job prospects, Marcos was pushed into work at an artisanal mining operation, where an accident on the job severely damaged his leg and forced him from any kind of physical labor. Reflecting on the pain and shame of losing his land, Marcos observed: "I felt bad, because people know I can farm ... but in the end I ended up with nothing." He also lamented the loss of confianza (reciprocal trust) among friends and neighbors due to the stigma of his migration fracaso, which substantially limits his ability to borrow land or capital in town. "People saw that I always worked hard; they trusted me with loans. But now that I've lost everything life is more difficult ... Because I couldn't pay the debt, they think I can't pay." He added: "they don't want to rent land to me because I lost what I had and I was deported." Marcos now survives by fixing small electronics and picking up odd jobs. He still hopes to one day make it back to the US but lacks any additional assets to mortgage in order to pay the smuggling fees. He plans to slowly work his way through Mexico to the border, and then somehow secure the funds needed to cross.

Marcos's migration trajectory underscores the need for research to expand and explore categories beyond the migrant and non-migrant binary to accommodate for uneven experiences and outcomes among those who sojourn. The lived experiences and implications of migration among fracasados like Marcos are profoundly different than those of their "successful" counterparts, and subsequently drive distinct forms of agrarian change. The need for additional categorical complexity becomes more pronounced for migrants who have experienced both "success" and "failure" across distinct migration attempts.

Raúl, for example, successfully reached the US in 2004 after using his land to borrow $\$ 4600$ at 10\% monthly interest from a local lender. Although the high interest pushed his debt up to approximately $\$ 6000$, he was able to pay back his loan through steady work in the US. Eventually he purchased a few small parcels - 0.5 cuerdas ( 0.022 hectares) in town and more in the nearby mountains-and also built a new house for his family back home. After injuring his hand at work in 2010, he voluntarily returned to Guatemala. He attempted to continue farming, yet, like Marcos, his investment in agriculture backfired: "There are no earnings [in agriculture], you always waste money ... instead of earning money you lose it all." "What did I do? I went again." Raúl left again in 2012 for $\$ 8000$ from two separate $\$ 2600$ loans from local lenders at $6 \%$ monthly interest, an additional $\$ 2000$ loan from a local bank at 3\% monthly interest, and some savings. Although he made it to Texas, Raúl struggled to find steady work and after two years was detained and deported before he could pay his loans in full. Encountering limited wages and work opportunities back in Guatemala, the debt quickly became insurmountable. "Even though you want to work day and night ... I can't do enough to get rid of it." Within a year and half of being deported, Raúl's total debt had climbed to $\$ 20,000$, with one moneylender raising the interest rate due to delayed repayment.

While weighing a new return attempt to save their mortgaged properties, Raúl's son offered to go in his place. They managed to borrow $\$ 4600$, interest free, from Raúl's brother in law in the US to cover the smuggling advance, yet Raúl's son was detained and deported on three separate attempts. Seeing no alternatives, Raúl was ultimately forced to sell the land and house acquired from his initial stint in the US. The entire sale went to the smuggling debts-nothing remained "even for a bit of food" or to pay the outstanding loan for his son's attempts. Tellingly, and tragically, Raúl's house was bought by a migrant in the US planning his eventual return. Raúl now rents a house far removed from his old neighborhood so as not to be reminded of his loss. He now relies on intermittent jornadas for work and rents some land to grow his own maize for household consumption. Yet, between renting a house and land and covering basic living expenses, his income often falls short: "there are months when you really struggle." Like Edwin and Marcos, Raúl harbors hope of one day returning to the US to recoup what he lost but lacks the resources to do so. 


\section{Conclusions}

This article reveals some of the ways in which contemporary migration under expanding border and immigration enforcement reworks landscapes and livelihoods in migrant-sending regions. Jokisch correctly observes that understanding the implications of migration for agrarian change in migrant-sending regions "must begin with understanding the political economic and environmental context from which migrants leave and to which they remit money" [7] (p. 546). Yet, in view of the experiences of failed migrants, I argue that scholars must also strive to understand the fluidity and unevenness engrained in the process of migration itself to fully assess the implications of migration for agrarian change and other dynamics in sending regions. This necessitates a careful analysis of the growing costs, perils, and hardships of undocumented journeys under expanded border and immigration enforcement. Closer attention to these dynamics reveals other "channels" of agrarian change beyond remittance inflows and local labor loss emphasized in the literature. As the cases above illustrate, migration can instead result in capital extraction, forced property transfers, and heightened labor exploitation. These findings also underscore the importance of expanding research categories beyond the migrant-non-migrant binary to accommodate for the uneven outcomes experienced within migrant cohorts that drive processes of agrarian change in profoundly different ways.

A number of themes presented in this article are in need of further examination. First, while this research has sought to identify conceptual gaps and new dynamics revealed through a close study of the lived experiences of deportees and other failed migrants, additional research is needed to ascertain the true scale and aggregate outcomes of border and immigration enforcement for migrant-sending communities across various geographic and temporal scales. Second, as with all processes of agrarian change, we can expect enforcement landscapes to be mediated by a number of situated social, cultural, political, and economic variables as they exist in distinct migrant-sending regions. Additional comparative research on these dynamics in Guatemala is forthcoming, yet we urgently need new scholarship exploring the diverse forms and implications of enforcement landscapes emerging in unique migrant-sending regions globally.

Third, additional research is needed to uncover the fate of transferred properties. Early evidence from fieldwork in Guatemala strongly indicates that many dispossessed and sold properties ultimately end up in the hands of "successful" migrants investing in homes and properties with capital from the US. Additional research is needed to reveal how "remittance landscapes" and "enforcement landscapes" may therefore be co-produced. Finally, the possibility of shifting enforcement strategies under the new Biden administration, including the suspension of the Migrant Protection Protocol and other enforcement practices, warrants additional research on how emerging changes to enforcement practices alter the experiences, strategies, and outcomes of contemporary migration. These changes underscore the importance of longitudinal research on enforcement landscapes amid shifting migrant responses to deportation and dispossession, as well as the dynamic policies and practices of border and immigration enforcement itself.

Funding: This research was funded through the Fulbright-Hays Doctoral Dissertation Research Abroad Program (P022A120010) and the National Science Foundation Graduate Research Fellowship Program (DGE-1143953). Earlier fieldwork was supported by the National Science Foundation under Grant Number 1056811 (P.I. Claudia Radel, Utah State University).

Institutional Review Board Statement: This study was conducted according to the guidelines of the Declaration of Helsinki, and approved by the Institutional Review Board of the University of Arizona (protocol number 1710920842, 7 November 2017).

Informed Consent Statement: Informed consent was obtained from all subjects involved in this study.

Data Availability Statement: Following privacy and confidentiality agreements with research participants the data for this article are not available publicly or upon request. 
Acknowledgments: The author would like to thank local leaders and research participants in Llanos del Pinal, Quetzaltenango, and Caballo Blanco, Retalhuleu for approving and supporting this research. The author extends thanks the editors of this special issue and to three anonymous reviewers for their helpful comments. Additional gratitude is due to Ursula Roldán Andrade, Jennifer Casolo, Brinton Lykes, and Elizabeth Oglesby for their support. Any errors and criticisms are to be reserved for the author.

Conflicts of Interest: The author declares no conflict of interest. The funders had no role in the design of the study; in the collection, analyses, or interpretation of data; in the writing of the manuscript, or in the decision to publish the results.

\section{References}

1. Durand, J.; Massey, D. Mexican Migration to the United States: A Critical Review. Latin Am. Stud. Assoc. 1992, $27,3-42$.

2. Massey, D.; Alarcón, R.; Durand, J.; González, H. Return to Aztlan: The Social Process of International Migration from Western Mexico; University of California Press: Oakland, CA, USA, 1987.

3. Reichert, J. The Migration Syndrome: Seasonal U.S. Wage Labor and Rural Development in Central Mexico. Hum. Organ. 1981, 40, 56-66. [CrossRef]

4. Cole, R.; Wong, G.; Brockhaus, M. Reworking the Land: A Review of Literature on the Role of Migration and Remittances in the Rural Livelihoods of Southeast Asia. CIFOR Working Paper 187. 2015. Available online: https://www.cifor.org/knowledge/publication/ $5621 /$ (accessed on 12 October 2020).

5. Deshingkar, P. Environmental Risk, Resilience, and Migration: Implications for Natural Resource Management and Agriculture. Environ. Res. Lett. 2012, 7, 015603. [CrossRef]

6. Hostettler, S. Land Use Changes and Transnational Migration: The Impact of Remittances in Western Mexico. Ph.D. Thesis, Ecole Polytechnique Fédéral de Lausanne, Lausanne, Switzerland, 2007. Unpublished.

7. Jokisch, B. Migration and Agricultural Change: The Case of Smallholder Agriculture in Highland Ecuador. Hum. Ecol. 2002, 30, 235-256. [CrossRef]

8. Jokisch, B.; Radel, C.; Carte, L.; Schmook, B. Migration Matters: How Migration is Critical to Contemporary Human-environment Geography. Geogr. Compass 2019, 13, e12460. [CrossRef]

9. Taylor, M.; Aguilar-Støen, A.; Castellanos, E.; Moran-Taylor, M.; Gerkin, K. International Migration, Land Use Change and the Environment in Ixcán, Guatemala. Land Use Policy 2016, 54, 290-301. [CrossRef]

10. Bestman, C. Militarized Global Apartheid. Curr. Anthropol. 2019, 60, S26-S38. [CrossRef]

11. Mountz, A. The Death of Asylum: Hidden Geographies of the Enforcement Archipelago; University of Minnesota Press: Minneapolis, MN, USA, 2020.

12. Nevins, J. Operation Gatekeeper and Beyond: The War on "Illegals" and the Remaking of the U.S.-Mexico Boundary; Routledge: New York, NY, USA, 2010.

13. Peutz, N.; De Genova, N. Introduction. In The Deportation Regime: Sovereignty, Space, and Freedom of Movement (1-29); De Genova, N., Peutz, N., Eds.; Duke University Press: Durham, UK, 2010.

14. Vogt, W. Crossing Mexico: Structural Violence and the Commodification of Undocumented Central American Migrants. Am. Ethnol. 2013, 40, 764-780. [CrossRef]

15. Dunn, T. Blockading the Border and Human Rights: The El Paso Operation that Remade Immigration Enforcement; University of Texas Press: Austin, TX, USA, 2009

16. Ewing, W. “Enemy Territory": Immigration Enforcement in the U.S.-Mexico Borderlands. J. Migr. Hum. Secur. $2014,2,198-222$.

17. Kovic, C.; Kelly, P. Migrant Bodies as Targets of Security Policies: Central Americans Crossing Mexico's Vertical Border. Dialect. Anthropol. 2017, 41,1-11. [CrossRef]

18. Slack, J. Deported to Death: How Drug Violence Is Changing Migration on the US-Mexico Border; University of California Press: Oakland, CA, USA, 2019.

19. Slack, J.; Martínez, D.; Lee, A.; Whiteford, S. The Geography of Border Militarization: Violence, Death, and Health in Mexico and the United States. J. Latin Am. Geogr. 2016, 15, 7-32. [CrossRef]

20. Martínez, D.; Heyman, J.; Slack, J. Border Enforcement Developments Since 1993 and How to Change CBP. Available online: https: //cmsny.org/publications/border-enforcement-developments-since-1993-and-how-to-change-cbp/ (accessed on 24 August 2019). [CrossRef]

21. United States Border Patrol (USBP). Border Patrol Agent Nationwide Staffing by Fiscal Year; 2019. Available online: https: / / www.cbp.gov/sites/default/files/assets / documents / 2020-Jan/U.S.\%20Border\%20Patrol\%20Fiscal\%20Year\%20Staffing\% 20Statistics\%20\%28FY\%201992\%20-\%20FY\%202019\%29_0.pdf (accessed on 12 October 2020).

22. International Organization of Migration (IOM). Perfil Migratorio de Guatemala 2012. IOM, 2013. Available online: https: / / publications.iom.int/books/perfil-migratorio-de-guatemala-2012 (accessed on 31 December 2020).

23. Abbot, J.U.S. Deportations of Guatemalans Doubled over Past Decade. Reuters. 3 January 2020. Available online: https: //www.reuters.com/article/us-usa-immigration-guatemala-idUSKBN1Z223M (accessed on 12 October 2020). 
24. Cohn, D.; Passel, J.; Gonzalez-Barrea, A. Rise in U.S. Immigrants from El Salvador, Guatemala and Honduras Outpaces Growth from Elsewhere. Pew Res. Cent. 2017. Available online: https://www.pewresearch.org/hispanic/2017/12/07/rise-in-u-simmigrants-from-el-salvador-guatemala-and-honduras-outpaces-growth-from-elsewhere/ (accessed on 7 November 2020).

25. International Organization of Migration (IOM). Missing Migrants: Tracking Deaths Along Migratory Routes. IOM, 2020. Available online: https:/ / missingmigrants.iom.int/region/americas?region=1407 (accessed on 7 November 2020).

26. Cornelius, W.; Salehyan, I. Does Border Enforcement Deter Unauthorized Immigration? The Case of Mexican Migration to the United States of America. Regul. Gov. 2007, 1, 139-153. [CrossRef]

27. Hiemstra, N. Detain and Deport: The Chaotic U.S. Immigration Enforcement Regime; University of Georgia Press: Athens, GA, USA, 2019.

28. Hiskey, J.; Córdova, A.; Malone, M.; Orcés, D. Crime Victimization, U.S. Deterrence Policy, and the Emigration Decision in Central America. Latin Am. Res. Rev. 2018, 53, 429-447. [CrossRef]

29. Johnson, R.; Woodhouse, M. Securing the Return: How Enhanced US Border Enforcement Fuels Cycles of Debt Migration. Antipode 2018, 50, 976-996. [CrossRef]

30. Massey, D.; Durand, J.; Pren, K. Why Border Enforcement Backfired. Am. J. Sociol. 2016, 121, 1557-1600. [CrossRef]

31. Slack, J.; Martínez, D.; Whiteford, S.; Peiffer, E. In Harm's Way: Family Separation, Immigration Enforcement Programs, and Security on the U.S.-Mexico Border. J. Migr. Hum. Secur. 2015, 3, 109-128.

32. Coleman, M.; Stuesse, A. The Disappearing State and the Quasi-event of Immigration Control. Antipode 2016, 48, 524-543. [CrossRef]

33. Boehm, D. Returned: Going and Coming in an Age of Deportation; University of California Press: Oakland, CA, USA, 2016.

34. Brotherton, D.; Barrios, L. Banished to the Homeland: Dominican Deportees and Their Stories of Exile; Columbia University Press: New York, NY, USA, 2011.

35. Golash-Boza, T. Deported: Immigrant Policing, Disposable Labor and Global Capitalism; New York University Press: New York, NY, USA, 2015.

36. Heidbrink, L. Migranthood: Youth in a New Era of Deportation; Stanford University Press: Redwood City, CA, USA, 2020.

37. Hiemstra, N. Geopolitical Reverberations of U.S. Migrant Detention and Deportation: A View from Ecuador. Geopolitics 2012, 17, 293-311. [CrossRef]

38. Peutz, N. Embarking on an Anthropology of Removal. Curr. Anthropol. 2006, 47, 217-241. [CrossRef]

39. Aguilar-Støen, M.; Taylor, M.; Castellanos, E. Agriculture, Land Tenure and International Migration in Rural Guatemala. J. Agrar. Chang. 2016, 16, 123-144. [CrossRef]

40. Bezares Cóbar, P. Diagnostico Sobre la Situación de los Deportados Guatemaltecos desde Estados Unidos, en 4 Comunidades de Origen de los Departamentos de Chimaltenango y Sacatepéquez. In Mesa Nacional para las Migraciones en Guatemala (MENAMIG); MENAMIG: Guatemala City, Guatemala, 2009.

41. Heidbrink, L. The Coercive Power of Debt: Migration and Deportation of Guatemalan Indigenous Youth. J. Latin Am. Caribb. Anthropol. 2019, 24, 263-281. [CrossRef]

42. Stoll, D. El Norte or Bust! How Migration Fever and Microcredit Produced a Financial Crash in a Latin American Town; Rowman \& Littlefield: Lanham, MD, USA, 2012.

43. Edelman, M.; Wolford, W. Introduction: Critical Agrarian Studies in Theory and Practice. Antipode 2017, 49, 959-976. [CrossRef]

44. Hiemstra, N. Pariscoping as a Feminist Methodological Approach for Researching the Seemingly Hidden. Prof. Geogr. 2017, 2, 329-336. [CrossRef]

45. Massaro, V.; Williams, J. Feminist Geopolitics. Geogr. Compass 2013, 7, 567-577. [CrossRef]

46. Radel, C.; Schmook, B.; Carte, L.; Mardero, S. Toward a Political Ecology of Migration: Land, Labor Migration, and Climate Change in Northwestern Nicaragua. World Dev. 2018, 108, 263-273. [CrossRef]

47. Mines, R.; de Janvry, A. Migration to the United States and Mexican Rural Development: A Case Study. Am. J. Agric. Econ. 1982, 64, 444-454. [CrossRef]

48. Cohen, J. Remittance Outcomes and Migration: Theoretical Contests, Real Opportunities. Stud. Comp. Int. Dev. 2005, 40, 88-112. [CrossRef]

49. de Haas, H. Remittances, Migration and Social Development: A Conceptual Review of the Literature. Soc. Policy Dev. Programme Pap. 2007, 34. Available online: http:/ / www.unrisd.org/80256B3C005BCCF9/(httpAuxPages)/8B7D005E37FFC77EC12573A600 439846/\$file/deHaaspaper.pdf (accessed on 7 November 2020).

50. de Haas, H. Migration and Development: A Theoretical Perspective. Int. Migr. Rev. 2010, 44, 227-264. [CrossRef]

51. Delgado Wise, R.; Márquez Covarrubias, H.; Puentes, R. Reframing the Debate on Migration, Development and Human Rights. Popul. Space Place 2013, 19, 430-443. [CrossRef]

52. Hecht, S.; Gomes, I.; Cuellar, N.; Rosa, H. Globalization, Forest Resurgence, and Environmental Politics in El Salvador. World Dev. 2006, 34, 308-323. [CrossRef]

53. Kay, C. Reflections on Latin America Rural Studies in the Neoliberal Globalization Period: A New Rurality? Dev. Chang. 2008, 39, 915-943. [CrossRef]

54. Lambin, E.; Meyfroidt, P. Global Land Use Change, Economic Globalization, and the Looming Land Scarcity. Proc. Natl. Acad. Sci. USA 2010, 108, 3465-3472. [CrossRef]

55. Aguilar-Støen, M. 'Con Nuestro Propio Esfuerzo': Understanding the Relationships between International Migration and the Environment in Guatemala. Eur. Rev. Latin Am. Caribb. Stud. 2012, 93, 25-40. [CrossRef] 
56. Durand, J.; Parrado, E.; Massey, M. Migradollars and Development: A Reconsideration of the Mexican Case. Int. Migr. Rev. 1996, 30, 423-444. [CrossRef]

57. Davis, J.; Lopez-Carr, D. Migration, Remittances and Smallholder Decision-making: Implications for Land Use and Livelihood Change in Central America. Land Use Policy 2014, 36, 319-329. [CrossRef]

58. Schmook, B.; Radel, C. International Labor Migration from a Tropical Development Frontier: Globalizing Households and an Incipient Forest Transition. Hum. Ecol. 2008, 36, 891-908. [CrossRef]

59. Moran-Taylor, M.; Taylor, M. Land and Leña: Linking Transnational Migration, Natural Resources, and the Environment in Guatemala. Popul. Environ. 2010, 32, 198-215. [CrossRef]

60. Taylor, M.; Moran-Taylor, M.; Rodman Ruiz, D. Land, Ethnic, and Gender Change: Transnational Migration and its Effects on Guatemalan Lives and Landscapes. Geoforum 2006, 37, 41-61. [CrossRef]

61. Radel, C.; Jokisch, B.; Schmook, B.; Carte, L.; Aguilar-Støen, M.; Hermans, K.; Zimmerer, K.; Aldrich, S. Migration as a Feature of Land System Transitions. Curr. Opin. Environ. Sustain. 2019, 38, 103-110. [CrossRef]

62. Radel, C.; Schmook, B. Migration and Gender: The Case of a Farming Ejido in Calakmul, Mexico. Yearb. Assoc. Pac. Coast Geogr. 2009, 71, 144-163. [CrossRef]

63. McKay, D. Cultivating New Local Futures: Remittance Economies and Land-use Patterns in Ifugao, Philippines. J. Southeast Asian Stud. 2003, 34, 285-306. [CrossRef]

64. Bialasiewicz, L. Off-shoring and Out-sourcing the Borders of Europe: Libya and EU Border Work in the Mediterranean. Geopolitics 2012, 17, 843-866. [CrossRef]

65. Mountz, A. The enforcement archipelago: Detention, Haunting, and Asylum on Islands. Political Geogr. 2011, 30, 118-128. [CrossRef]

66. Tazzioli, M.; Garelli, G. Containment Beyond Detention: The Hotspot System and Disrupted Migration Movements Across Europe. Environ. Plan. D Soc. Space 2018, 38, 1009-1027. [CrossRef]

67. Cornelius, W. Death at the Border: Efficacy and Unintended Consequences of U.S. Immigration Control Policy. Popul. Dev. Rev. 2001, 27, 661-685. [CrossRef]

68. de León, J. The Land of Open Graves: Living and Dying on the Migrant Trail; University of California Press: Oakland, CA, USA, 2015.

69. Coleman, M. Immigration Geopolitics Beyond the Mexico-U.S. Border. Antipode 2007, 39, 54-76. [CrossRef]

70. Miller, T. Border Patrol Nation: Dispatches from the Front Lines of Homeland Security; City Lights Open Media: San Francisco, CA, USA, 2014.

71. Hiemstra, N. Pushing the US-Mexico Border South: United States' Immigration Policing Throughout the Americas. Int. J. Migr. Bord. Stud. 2019, 5, 44-63. [CrossRef]

72. Isacson, A.; Meyer, M.; Smith, H. Mexico's Southern Border: Security, Central American Migration, and U.S. Policy. Washington Office on Latin America Report. 29 June 2017. Available online: https:/ / www.wola.org/analysis/wola-report-mexicos-southernborder-security-central-american-migration-u-s-policy / (accessed on 7 November 2020).

73. Arriola Vega, L. Mexico's Not-So-Comprehensive Southern Border Plan. Baker Institute for Public Policy Issue Brief. 5 August 2016. Available online: https:/ / hdl.handle.net/1911/92470 (accessed on 7 November 2020).

74. Miller, T.; Nevins, J. Beyond Trump's Big, Beautiful Wall. NACLA Rep. Am. 2017, 49, 145-151. [CrossRef]

75. Isacson, A. 400 Miles of Harm: There Is Nothing to Celebrate about Border Wall Construction. Washington Office on Latin America Commentary. 29 October 2020. Available online: https:/ / www.wola.org/analysis/400-miles-of-harm-nothing-to-celebrate-aboutborder-wall-construction/ (accessed on 26 November 2020).

76. Chontiner, I. Inside a Texas Building Where the Government Is Holding Immigrant Children. The New Yorker. 22 June 2019. Available online: https:/ / www.newyorker.com/news/q-and-a/inside-a-texas-building-where-the-government-is-holdingimmigrant-children (accessed on 12 October 2020).

77. Southern Poverty Law Center (SPLC). Family Separation Under the Trump Administration-A Timeline. Southern Poverty Law Center. 17 June 2020. Available online: https: / / www.splcenter.org/news/2020/06/17/family-separation-under-trumpadministration-timeline (accessed on 7 November 2020).

78. Democratic Staff Report (DSR). DHS Run Amok? A Reckless Overseas Operation, Violation, and Lies. Democratic Staff Report Prepared for the Use of the Committee on Foreign Relations, United States Senate. 2020. Available online: https: / / www.foreign.senate.gov/imo/media/doc/Final\%20INL\%20DHS\%20Report.pdf (accessed on 2 January 2021).

79. Bruno, A. Immigration: U.S. Asylum Policy; Congressional Research Service: Washington, DC, USA, 2019 ; p. R45539.

80. Human Rights First (HRF). Humanitarian Disgrace: U.S. Continues to Illegally Block, Expel Refugees to Danger. Human Rights First. 16 December 2020. Available online: https:/ / www.humanrightsfirst.org/resource/humanitarian-disgrace-us-continuesillegally-block-expel-refugees-danger (accessed on 31 December 2020).

81. Physicians for Human Rights (PHR). Unsafe, Unsanitary, Inhumane: PHR Medical Expert's Observations at the Matamoros Migrant Encampment. Physicians for Human Rights. 26 September 2019. Available online: https://phr.org/news/phr-statementon-migrant-protection-protocols/ (accessed on 12 October 2020).

82. Ryo, E. How ICE Enforcement Has Changed Under the Trump Administration. The Conversation. 29 July 2019. Available online: https: / / theconversation.com/how-ice-enforcement-has-changed-under-the-trump-administration-120322 (accessed on 12 October 2020). 
83. Semple, K. Migrants in Mexico Face Kidnappings and Violence While Awaiting Immigration Hearings in U.S. The New York Times. 19 July 2019. Available online: https:/ / www.nytimes.com/2019/07/12/world/americas/mexico-migrants.html (accessed on 7 November 2020).

84. Médecins Sans Frontières (MSF). More People Kidnapped, Abused on Migration Route in Southern Mexico. Médecins Sans Frontières. 30 October 2019. Available online: https://www.msf.org/increase-kidnappings-and-violence-against-migrantssouthern-border-mexico (accessed on 7 November 2020).

85. Murdza, K. Biden Took 3 More Executive Actions on Immigration. Did He Go Far Enough? American Immigration Council. 3 February 2021. Available online: https:/ immigrationimpact.com/2021/02/03/immigration-executive-orders-february-2021/ (accessed on 9 February 2021).

86. Burridge, A.; Gill, N.; Kocher, A.; Martin, L. Polymorphic Borders. Territ. Politics Gov. 2017, 5, 239-251. [CrossRef]

87. Jonas, S.; Rodríguez, N. Guatemala-U.S. Migration: Transforming Regions; University of Texas Press: Austin, TX, USA, 2014.

88. Instituto Guatemalteco de Migración (IGM). Informes Estadísticos. 2020. Available online: https://igm.gob.gt/ (accessed on 12 October 2020).

89. Rubio-Goldsmith, R.; McCormick, M.; Martínez, D.; Duarte, I. The 'Funnel Effect' and Recovered Bodies of Unauthorized Migrants Processed by the Pima County Office of the Medical Examiner, 1990-2005. Binatl. Migr. Inst. Univ. Ariz. 2006. Available online: https: / / papers.ssrn.com/sol3/papers.cfm?abstract_id=3040107 (accessed on 26 October 2020). [CrossRef]

90. Boyce, G.; Chambers, S.; Launius, S. Bodily Inertia and the Weaponization of the Sonoran Desert in US Boundary Enforcement: A GIS Modeling of Migration Routes through Arizona's Altar Valley. J. Migr. Hum. Secur. 2019, 7, 23-35. [CrossRef]

91. Reineke, R.; Martínez, E. Migrant Deaths in the Americas (United States and Mexico). In Fatal Journeys: Tracking Lives Lost during Migration (45-84); Brian, T., Laczko, F., Eds.; International Organization for Migration: Geneva, Switzerland, 2014.

92. Carte, L.; Schmook, B.; Radel, C.; Johnson, R. The Slow Displacement of Smallholder Farming Families: Land, Hunger, and Labor Migration in Nicaragua and Guatemala. Land 2019, 8, 89. [CrossRef]

93. Boyce, G. Immigration, Policing, and the Politics of Time. Geogr. Compass 2020, 14, e12496. [CrossRef]

94. Harrison, J.; Lloyd, S. Illegality at Work: Deportability and the Productive New Era of Immigration Enforcement. Antipode 2011, 44, 365-385. [CrossRef]

95. Boyce, G.; Launius, S. The Immigration Dragnet and the Dispossession of Household and Community Wealth in the United States. Binatl. Migr. Inst. 2019. Available online: https://bmi.arizona.edu/sites/default/files/publication-files/Immigration\%20 Dragnet\%20Report\%202019.pdf (accessed on 26 October 2020).

96. Smith, S. The Domestication of Geopolitics: Buddhist-Muslim Conflict and the Policing of Marriage and the Body in Ladakh, India. Geopolitics 2009, 14, 197-218. [CrossRef]

97. Slack, J.; Martínez, D. Postremoval Geographies: Immigration Enforcement and Organized Crime on the U.S.-Mexico Border. Ann. Am. Assoc. Geogr. 2020, 1-17. [CrossRef]

98. Grandin, G. The Blood of Guatemala: A History of Race and Nation; Duke University Press: Durham, UK, 2000.

99. McCreery, D. Rural Guatemala, 1760-1940; Stanford University Press: Redwood City, CA, USA, 1994.

100. Alonso-Fradejas, A. Anything but a Story Foretold: Multiple Politics of Resistance to the Agrarian Extractivist Project in Guatemala. J. Peasant Stud. 2015, 42, 489-515. [CrossRef]

101. Isakson, S.R. Maize Diversity and the Political Economy of Agrarian Restructuring in Guatemala. J. Agrar. Chang. 2014, 14, 347-379. [CrossRef]

102. Velázquez Nimatuj, I. “A Dignified Community Where We Can Live": Violence, Law, and Debt in Nueva Cajola's Struggle for Land. In War by Other Means: Aftermath in Post-Genocide Guatemala (170-194); McAllister, C., Nelson, D., Eds.; Duke University Press: Durham, UK, 2013.

103. Gauster, S.; Isakson, S.R. Eliminating Market Distortions, Perpetuating Rural Inequality: An Evaluation of Market-assisted Land Reform in Guatemala. Third World Q. 2007, 28, 1519-1536. [CrossRef]

104. United States Agency for International Development (USAID). Land Links: Guatemala. 2020. Available online: www.land-links. org/country-profile/guatemala/ (accessed on 12 October 2020).

105. Instituto Nacional de Estadística (INE). Encuesta Nacional de Empleo y Ingresos 1-2016. 2016. Available online: https: / / www.ine.gob.gt (accessed on 12 October 2020).

106. Blitzer, J. How Climate Change is Fueling the U.S. Border Crisis. The New Yorker. 3 April 2019. Available online: https: //www.newyorker.com/news/dispatch/how-climate-change-is-fuelling-the-us-border-crisis (accessed on 26 October 2020).

107. Lustgarten, A. The Great Climate Migration. The New York Times. 23 July 2020. Available online: https:/ / www.nytimes.com/ interactive/2020/07/23/magazine/climate-migration.html (accessed on 12 October 2020).

108. Kitroeff, N. Two Hurricanes Devastated Central America. Will the Ruin Spur a Migration Wave? The New York Times. 4 December. Available online: https:/ /www.nytimes.com/2020/12/04/world/americas/guatemala-hurricanes-mudslide-migration.html (accessed on 18 February 2021).

109. Gerber, J.-F. The Role of Rural Indebtedness in the Evolution of Capitalism. J. Peasant Stud. 2014, 41, 729-747. [CrossRef]

110. Garni, A. Mechanisms of Migration: Poverty and Social Instability in the Postwar Expansion of Central American Migration to the United States. J. Immigr. Refug. Stud. 2010, 8, 316-338. [CrossRef] 